the view over London from Westfield College.

Those who knew Bill Klyne, whether professionally or personally, felt a strong bond of affection, coupled with admiration and respect for his strength of character and his integrity. $\mathrm{He}$ showed deep concern for others, and particularly for his colleagues and their families, many of whom have reason to be grateful for his help or sound advice in resolving personal or professional problems. His kindness was invariably combined with a great sense of fairness and propriety: always meticulous in his dealings with friends and associates, he expected high standards of them, but none more rigorous than those he demanded of himself.

He leaves his wife, Barbara, their son Michael, and daughter Janey.

D. N. Kirk

P. M. Scopes

\section{F. Bates}

Leslie Fleetwood Bates died peacefully on 20 January 1978 , after a short illness, at Nottingham, the city where he had made his home for over forty years. With his death the study of magnetism in Great Britain has lost one of its most distinguished elder statesmen and its most passionate advocate.

He was born in March, 1897 at Kingswood, Bristol where he acquired that curious habit of speech in which the letter "l" is added to the end of words normally terminated by a vowel. The word which suffered most in this respect was "idea" and many of his research students were at some time puzzled by his enthusiastic description of what always sounded like "a good ideal for research".

Bates entered the University of Bristol in 1913 at the remarkably early age of 16. After graduation he immediately enlisted in the army and after a short period was sent to India where he was placed in charge of the $\mathrm{X}$-ray laboratory of the 9 th division with the rank of Captain.

In 1920 he returned to the University as a post-graduate student and began research in magnetism under the supervision of A. P. Chattock. He was required to determine the gyromagnetic ratio or Landé $g$-factor for ferromagnetic metals by a direct measurement of the angular impulse acquired by a ferromagnetic rod when it is magnetised. It was found, in all cases, that $g$ was close to 2 . For nearly fifty years it has been fashionable to present this result as evidence for the spin-only nature of ferromagnetism in iron and nickel. However, in an address to the Arbeitsgemeinschaft
Ferromagnetismus some fifty years later Bates reminded his audience that, at the time, the results were regarded as much needed evidence for the very existence of electron spin.

The records of the University of Bristol reveal that in 1921 "the Science Board recommended that $\mathrm{Mr}$. L. F. Bates be awarded the British Association Exhibition for the current year." It is not known whether he actually took up the exhibition since he left Bristol in 1922 for Cambridge. There, in the Cavendish Laboratory he undertook research concerned with long-range alpha particles under the supervision of Lord Rutherford. Bates was very proud of his association with Rutherford, but it is difficult to avoid the impression that neither of them was inspired by the topic and when Bates left Cambridge for a lectureship at University College, London, it was to magnetism that he turned his attention.

He engaged in studies on permanent magnets using the magnetic potentiometer, that invention of Chattock's which fascinated Bates all his life; magnetic susceptibility studies on amalgams and, very much in advance of the time, the magnetic properties of compounds of manganese. He prepared $\mathrm{MnAs}$ and $\mathrm{MnSb}$ and, in later life, bitterly regretted having been diverted from $\mathrm{MnBi}$ when, in the 1950 's, that compound looked like becoming the permanent magnet material of the future.

In 1936 he was appointed Lancashire-Spencer Professor of Physics at University College, Nottingham and for some thirty years Nottingham became almost synonymous with magnetism. With E. C. Stoner at Leeds and W. Sucksmith at Sheffield expertise in magnetism became so heavily concentrated in the three universities that the region was often referred to as the "magnetic belt". At Nottingham Bates embarked on his elegant and successful method for measuring temperature changes during the hysteresis cycle of ferromagnets and, during the war, acted as adviser to the Inter-Services Research Bureau where he was particularly concerned with the degaussing of ships.

Towards the end of the war he persuaded the Electrical Research Association to support some work on magnetic domain (Bitter) patterns. At a distance of thirty years this looks like a logical complement to the work on the heat of hysteresis. In fact it is an example of Bates' highly intuitive approach to physics. The current state of Bitter patterns at the time is admirably summed up in four photographs reprinted in Becker and Döring's Ferromagnetismus which had appeared in 1939. They present a picture of be- wildering complexity and give no indication whatsoever of the powerful tool the technique was to become. The breakthrough was made in the U.S.A. but when it came Bates and his students were poised to exploit it and immediately provided a dramatic experimental verification of a remarkable and unexpected prediction by Néel that domain sizes in crystals of certain shapes would actually shrink in the presence of an external field.

University College, Nottingham, became Nottingham University in 1948. Bates, who had always played an active role in university affairs found himself in demand at all levels of university life. He served on all its important committees and was Deputy ViceChancellor from 1953 to 1956. After retirement in 1964 he remained very active. He was very proud of his association with the University of London and was only too pleased to retain this association through a long period as one of its external examiners. He was Chairman of the Royal Society's Symbols Committee and was responsible for producing its most recent publication Quantities, Units and Symbols. But magnetism remained his greatest love. He attended all the important international conferences, his last appearance being at ICM-76, Amsterdam. Until last year, when illhealth restricted his mobility, he was to be seen at every meeting of the Institute of Physics' Magnetism Group, usually in conversation with one of his former students in whose work and welfare he took a genuine and often fatherly interest.

As a man he had a transparent and child-like honesty that left no room for subterfuge or intrigue. He was never afraid to speak his mind and those who knew only his gentle demeanour were often taken aback by his forthright and often wrathful denunciation of any underhand manoeuvre or selfseeking enterprise.

By nature gregarious, his very active social life was somewhat curtailed after the death of his wife shortly after his own retirement and there were times when he must have been a very lonely man. In later years he derived great pleasure from his membership of the Athenaeum where he frequently entertained his former colleagues and students to dinner. On these occasions the years would roll away, the boisterous good humour and high spirits of his former glory would return; and as the conversation ebbed and flowed a chance remark would reveal the remarkable insight and compassion of the man whom we shall always remember with admiration and affection.

E. W. Lee 